Abdel Aziz Fouda*1, Salah Mohmed Rashwan², Mona Abdelfatah ${ }^{1}$

${ }^{1}$ El-Mansoura University, Department of Chemistry, Faculty of Science, El-Mansoura-35516, Egypt, ${ }^{2}$ Suez Canal University, Department of Chemistry, Faculty of Science, Ismailia, Egypt
Scientific paper

ISSN 0351-9465, E-ISSN 2466-2585

UDC:620.197.3

doi: $10.5937 /$ zasmat $1901003 \mathrm{~F}$

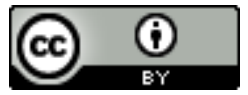

Zastita Materijala $60(1)$

$3-17(2019)$

\title{
Corrosion Inhibition of stainless steel 304 in hydrochloric acid solution using clindamycin antibiotic as Eco-friendly inhibitor
}

\begin{abstract}
The corrosion protection of stainless steel 304 (SS 304) in $2 \mathrm{M} \mathrm{HCl}$ solutions using Clindamycin antibiotic was investigated by weight loss (WL), electrochemical frequency modulation (EFM), electrochemical impedance spectroscopy (EIS) and potentiodynamic polarization (PP) tests. Electrochemical results showed that this compound is an efficient inhibitor for SS304 and the efficiency reached $93 \%$ at 300 ppm. The inhibition efficiency (IE) increases with the drug concentration and decreases with rising temperature. Data from electrochemical measurements suggested that the drug functioned by adsorption of the molecule on the metal/corroding interface, inhibiting both the cathodic and anodic half-reactions of the corrosion process. The adsorption of this drug on SS304 surface follows Langmuir adsorption isotherm. The thermodynamic functions of activation and adsorption processes were calculated and discussed. The surface morphology of the SS304 specimens was evaluated using atomic force microscopy (AFM) and Fourier transform infrared spectroscopy (FTIR).
\end{abstract}

Keywords: SS 304, Corrosion inhibition, HCl, AFM, FTIR, Clindamycin antibiotic.

\section{INTRODUCTION}

SS 304 has found wide applications in a variety of industries. It is covered with a highly protective film of chromium oxyhydroxides and is resistant to corrosion in many aggressive environments. Hydrochloric acid solution readily attacks SS 304. It is possible to reduce the corrosion rate to a safe level by adding inhibitors [1,2]. It is notable that corrosion never stops however its extension and seriousness can be brought down. Nonetheless, corrosion control is a basic issue from an application perspective and it has been accounted for that inhibitors are should have been utilized which go about as an obstruction to lessen the environment aggressive against the corrosion pitting assault [3-7]. Among the acid solutions, hydrochloric acid is one of the most widely used regular aggressive solutions [8-11]. Heterocyclic compounds such as an antibiotic (pharmaceutical drugs) can provide excellent inhibition.

\footnotetext{
${ }^{*}$ Corresponding author: A. S. Fouda

E-mail: asfouda@mans.edu.eg

Paper received: 28. 06. 2018.

Paper corrected: 12.08.2018.

Paper accepted: 25. 08. 2018.

Paper is available on the website: www.idk.org.rs/journal
}

These molecules depend at most on certain physical properties of the inhibitor molecules such as functional groups, steric factors, electron density at the donor atom and electronic structure of the molecules [12]. A few researchers have been reminding the use of antibacterial drugs as corrosion inhibitors because of the presence of oxygen, nitrogen and sulphur in their structures as active centers, high solubility in water, high molecular size, non-toxic "environmentally friendly" corrosion inhibitors, important in biological reactions and drugs that can be easily produced and purified [13-20]. In recent years the use of drugs as corrosion inhibitors for different metals due to their non-toxic nature, namely Cefadroxil, Ciprofloxacin, Norfloxacin, Ofloxacin drugs, Tacrine have paid attention to by some authors [21-23].

The use of drugs as corrosion inhibitors is due to the presence of $\pi$ electrons, hetero atoms in their molecules through which they are either adsorbed or form an insoluble metal complex at the metal surface and inhibit metal corrosion [24]. Clindamycin is an antibiotic useful for the treatment of a number of bacterial infections [25].

The objective of this study is to investigate the corrosion behavior of SS 304 in $2 \mathrm{M} \mathrm{HCl}$ at different temperatures in the presence of Clindamycin antibiotic using chemical and electrochemical 
techniques. The surface morphology of the SS 304 specimens also, was analyzed.

\section{EXPERIMENTAL TECHNIQUES}

\subsection{Materials}

For chemical measurements, SS304 specimen with an exposed surface area of $(2 \times 2 \times 0.2 \mathrm{~cm}) \times$

Table 1. Chemical composition (weight \%) of the SS304

Tabela 1. Hemijski sastav (težinski\%) SS304
2 faces was used and for electrochemical tests, the exposed surface area of metal was $1 \mathrm{~cm}^{2}$. Prior to each experiment, the surface of SS 304 specimens was abraded with the finest grade emery papers to mirror finish, rinsed with acetone and finally washed with twice distilled water.

\begin{tabular}{|l|c|c|c|c|c|c|c|}
\hline Element & $\mathrm{C}$ & $\mathrm{Si}$ & $\mathrm{Mn}$ & $\mathrm{Cr}$ & $\mathrm{P}$ & $\mathrm{Ni}$ & $\mathrm{Fe}$ \\
\hline Weight (\%) & 0.08 & 0.75 & 2.0 & $18-20$ & 0.045 & 10.5 & the rest \\
\hline
\end{tabular}

\subsection{Chemicals and solutions}

The pharmaceutical compound has been investigated named Clindamycin which purchased from Memphis company, Cairo, Egypt. The investigated pharmaceutical drug is used as received and chosen because it is easily soluble in water, has a high molecular weight, cheap, available and contains many donating atoms $(\mathrm{N}, \mathrm{O}$, and $\mathrm{P})$. All the solutions were prepared from AR grade chemicals using twice distilled water. The aggressive solutions used were made from $37 \% \mathrm{HCl}$, appropriate concentrations of acid were prepared using twice distilled water. 1000 $\mathrm{ppm}$ stock solutions from the investigated drug were prepared by dissolving one gram /liter of the solid pharmaceutical drug in twice distilled water; the other concentrations of the pharmaceutical drug $(50-300 \mathrm{ppm})$ were prepared by dilution with twice distilled water. All the materials used were of AR grade and used as received.

Table 2. Molecular structure, formula and molecular weight of the investigated drug

Tabela 2. Molekularna struktura, formula I molekularna težina ispitivanog leka

\begin{tabular}{|c|c|c|c|}
\hline Inhibitor & Structure & Mol. Formula & Mol. Weight \\
\hline \multirow{2}{*}{ Clindamycin } & (nO & & \\
& &
\end{tabular}

\subsection{Methods}

\subsubsection{Weight Loss (WL) Measurements}

Coupons of SS 304 specimens were weighed and immersed in $100 \mathrm{ml}$ of the test solution in open beakers. The beakers were placed in a water bath maintained at $25^{\circ} \mathrm{C}$. Each sample of SS 304 was withdrawn from the test solution after every $30 \mathrm{~min}$, washed and dried in air before reweighing. The difference in weight after each interval was taken as the WL. The experiment was repeated at 25$45^{\circ} \mathrm{C}$. From the $\mathrm{WL}$ results, the (\% IE) of the drug, degree of surface coverage (è) and corrosion rate $\left(k_{\text {corr }}\right)$ were determined using the following equations [26]:

$$
\begin{aligned}
& \% I E=\theta \times 100=\left[1-\left(W_{1} / W_{2}\right)\right] \times 100 \\
& k_{\text {corr }}=W / A t
\end{aligned}
$$

were $W_{1}$ and $W_{2}$ are the weight losses for SS 304 in the presence and absence of the drug, $A$ is the area of the SS304 coupon $\left(\mathrm{cm}^{2}\right), t$ is the time of immersion (min) and $\mathrm{W}$ is the $\mathrm{WL}\left(\mathrm{mg} \mathrm{cm}^{-2}\right)$ of SS304 after time $t$ ( $\mathrm{min})$.

\subsubsection{Electrochemical measurements}

A three-electrode electrochemical cell was used. The working electrode (WE) was SS 304 of the surface area of $1 \mathrm{~cm}^{2}$. Before each experiment, the electrode was abraded using emery papers as before. After this, the electrode was cleaned ultrasonically with ethyl alcohol and washed by twice distilled water. All potentials were given with reference to (SCE). The counter electrode was a platinum plate of the surface area of $1 \mathrm{~cm}^{2}$. The WE was immersed in the test solution for $30 \mathrm{~min}$ until a steady state open circuit potential $\left(E_{\text {ocp }}\right)$ was 
obtained. The polarization curves were recorded by changing the potential from $-0.6 \mathrm{~V}$ to $0.2 \mathrm{~V}$ with a sweep rate of $1 \mathrm{mV} / \mathrm{s}$ and under air atmosphere [27]. All measurements were carried out with SS304 electrode in $2 \mathrm{M} \mathrm{HCl}$ in the absence and presence of different concentrations of the investigated drug at $25^{\circ} \mathrm{C}$. All experiments were carried out at $25^{\circ} \mathrm{C}$. The IE and $(\theta)$ were calculated from the following equation:

$\%$ IE $=\Theta \times 100=\left[1-\left(i_{\text {corr(inh) }} / i_{\text {corr(free })}\right] \times 100\right.$

where $\mathrm{i}_{\text {corr(free) }}$ and $\mathrm{i}_{\text {corr(inh) }}$ are the corrosion current densities in the absence and presence of inhibitor, respectively.

EIS measurements were performed using the same cell that used in polarization experiments .The EIS carried out over a frequency range of 1 $\mathrm{Hz}$ to $100 \mathrm{kHz}$, with a signal amplitude perturbation of $10 \mathrm{mV}$. The $(\% \mathrm{IE})$ and $(\theta)$ of the investigated drug obtained was calculated from the following equation:

$$
\% I E=\theta \times 100=\left[1-\left(R_{c t}^{\circ} / R_{c t}\right] \times 100\right.
$$

where $\mathrm{R}^{\circ}{ }_{\mathrm{ct}}$ and $\mathrm{R}_{\mathrm{ct}}$ are the charge transfer resistances in the absence and presence of the inhibitor, respectively.

EFM is a non-destructive technique as EIS that can directly and rapidly give values of the corrosion current without prior knowledge of Tafel constants. The great of the EFM is the causality factors, which serves as an internal check on the validity of the EFM measurement.With the causality factors, the experimental EFM data can be verified $[28,29]$. Identical cell assembly was used as in impedance studies. All electrochemical measurements were carried out using Potentiostat/Galvanostat/Zra analyzer (Gamry PCl4-G750). A personal computer with DC105 software for potentiodynamic, EIS300 software for EIS and EFM140 software for EMF and Echem Analyst 5.21 was used for data fitting.

\subsubsection{Surface Examinations}

The specimens of SS304 used for surface morphology examination were immersed in $2 \mathrm{M}$ $\mathrm{HCl}$ in the absence (blank) and presence of 300 ppm of Clindamycin at $25^{\circ} \mathrm{C}$ for one day. The analysis was performed using atomic force microscopy (AFM) (a Pico SPM2100 AFM device) operating in contact mode in the air at Nanotechnology Laboratory, Faculty of Engineering
Mansoura University. IR Affinity (Perkin-Elmer) spectrophotometer was used for recording the FTIR spectra to determine the composition of the corrosion product formed on the SS304 surface.

\section{RESULTS AND DISCUSSION}

\subsection{Weight loss (WL) measurements}

WL of SS304 was determined, at various time intervals, in the absence and presence of different concentrations of Clindamycin drug. All the experiments were performed at $25-45^{\circ} \mathrm{C}$. Values of corrosion rates $\left(\mathrm{k}_{\text {corr }}\right)$ and \% IE of Clindamycin drug are summarized in (Tables 3 and 4 ). Values of \% IE increases with increasing drug concentration (due to the increase of the surface coverage and due to the adsorption of drug molecule on the surface of SS304) and decreases with rising in temperature due to the increase of desorption of drug molecules from SS304 surface. The optimum concentration wanted to achieve an efficiency of $93 \%$ was found to be $300 \mathrm{ppm}$. In all cases, the increase in the inhibitor concentration was accompanied by a decrease in WL and an increase in the \%IE. These results lead to the conclusion that the Clindamycin drug under investigation is a fairly efficient inhibitor for SS304 dissolution in $\mathrm{HCl}$ solution. Fig. 1 shows the WL-time curves for the corrosion of $\mathrm{SS} 304$ in $2 \mathrm{M} \mathrm{HCl}$ solution in the absence and presence of Clindamycin drug at $25^{\circ} \mathrm{C}$.

Table 3. ( $\left.k_{\text {corr }}\right)$ and IE data obtained from WL measurements for SS 304 in $2 \mathrm{M} \mathrm{HCl}$ solution in the absence and presence of different concentrations of Clindamycin drug at $25^{\circ} \mathrm{C}$

Tabela 3. $\left(k_{\text {corr }}\right)$ i IE podaci dobijeni iz WL merenja za SS 304 u $2 \mathrm{M} \mathrm{HCl} \mathrm{u} \mathrm{odsustvu} \mathrm{i} \mathrm{prisustvu} \mathrm{razli-}$ čitih koncentracija leka Klindamicina na $25^{\circ} \mathrm{C}$

\begin{tabular}{|c|c|c|c|}
\hline Conc., ppm & $\begin{array}{c}\mathrm{k}_{\text {corr, }} \\
\mathrm{mg} \mathrm{cm}^{-2} \mathrm{~min}^{-1}\end{array}$ & $\theta$ & $\% \mathrm{IE}$ \\
\hline Blank & 0.046 & ---- & ---- \\
\hline 50 & 0.0054 & 0.883 & 88.3 \\
\hline 100 & 0.0046 & 0.901 & 90.1 \\
\hline 150 & 0.0040 & 0.912 & 91.2 \\
\hline 200 & 0.0036 & 0.921 & 92.1 \\
\hline 250 & 0.0031 & 0.933 & 93.3 \\
\hline 300 & 0.0029 & 0.936 & 93.6 \\
\hline
\end{tabular}


Table 4. Effect of Clindamycin drug concentrations on ( $\boldsymbol{\theta})$ and (\% IE) for SS304 in $2 \mathrm{M} \mathrm{HCl}$ at different temperatures and at 120 min immersion

Tabela 4. Uticaj koncentracije leka Klindamicina na (ө) i (\% IE) za SS304 u 2M HCl na različitim temperaturama i pri potapanju od $120 \mathrm{~min}$

\begin{tabular}{|c|c|c|c|c|c|c|c|c|}
\hline \multirow{2}{*}{ Conc. ppm } & \multicolumn{2}{|c|}{$30^{\circ} \mathrm{C}$} & \multicolumn{2}{c|}{$35^{\circ} \mathrm{C}$} & \multicolumn{2}{c|}{$40^{\circ} \mathrm{C}$} & \multicolumn{2}{c|}{$45^{\circ} \mathrm{C}$} \\
\cline { 2 - 10 } & $\theta$ & $\%$ IE & $\theta$ & $\%$ IE & $\theta$ & $\%$ IE & $\theta$ & \%IE \\
\hline 50 & 0.866 & 86.6 & 0.850 & 85.0 & 0.823 & 82.3 & 0.799 & 79.9 \\
\hline 100 & 0.875 & 87.5 & 0.862 & 86.2 & 0.842 & 84.2 & 0.816 & 81.6 \\
\hline 150 & 0.886 & 88.6 & 0.876 & 87.6 & 0.855 & 85.5 & 0.823 & 82.3 \\
\hline 200 & 0.898 & 89.8 & 0.891 & 89.1 & 0.864 & 86.4 & 0.838 & 83.8 \\
\hline 250 & 0.907 & 90.7 & 0.901 & 90.1 & 0.879 & 87.9 & 0.856 & 85.6 \\
\hline 300 & 0.923 & 92.3 & 0.914 & 91.4 & 0.900 & 90.0 & 0.879 & 87.9 \\
\hline
\end{tabular}

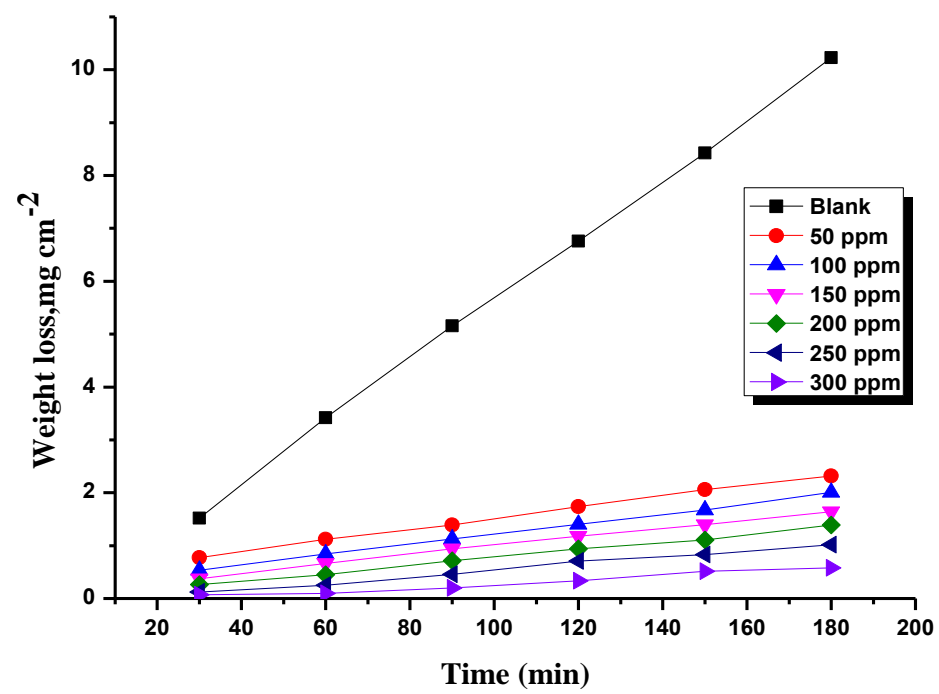

Figure 1. WL-time curves for the corrosion of SS304 in $2 \mathrm{M} \mathrm{HCl}$ solution in the absence and presence of Clindamycin drug at $25^{\circ} \mathrm{C}$

Slika 1. Krive WL-vreme za koroziju SS304 u $2 \mathrm{M} \mathrm{HCl}$ u odsustvu i prisustvu leka Klindamicin na $25^{\circ} \mathrm{C}$

\subsection{Effect of Temperature}

The effect of temperature on the corrosion parameters of SS 304 with the addition of Clindamycin drug was studied using WL method. A major advantage of this method is its relative simplicity and availability. The data of corrosion behavior of SS304 in $2 \mathrm{M} \mathrm{HCl}$ containing different concentrations of Clindamycin drug for $120 \mathrm{~min}$ in the temperature range $25-45^{\circ} \mathrm{C}$ were presented in (Table 4). Inspection of this Table reveals that the $\mathrm{k}_{\text {corr }}$ of SS304 increases with increasing temperature. On the other hand, the IE of Clindamycin drug decreased with raising temperature Fig.2. This suggests possible desorption of some of the adsorbed drug molecules from the metal surface at higher temperatures. Such behavior shows that the additives were physically adsorbed on the metal surface.
Arrhenius-type dependence is observed between corrosion rate and temperature often expressed as:

$$
k_{\text {corr }}=A \exp -E_{a}^{*} / R T
$$

where $E_{a}^{*}$ is the apparent activation energy, $R$ is the universal gas constant, $T$ is the absolute temperature, and $\mathrm{A}$ is the frequency factor. Fig. 3 depicts Arrhenius plot log $\mathrm{k}_{\text {corr }}$ against the reciprocal of temperature 1/T for SS 304 in $2 \mathrm{M} \mathrm{HCl}$ solution in the absence and presence of different Clindamycin concentrations. An alternative formulation of the Arrhenius equation is [30]:

$$
k_{\text {corr }}=R T / N h \exp \left(\Delta S^{*} / R\right) \exp \left(-\Delta H^{*} / R T\right)
$$

where $h$ is the Planck's constant and $N$ is the Avogadro's number 


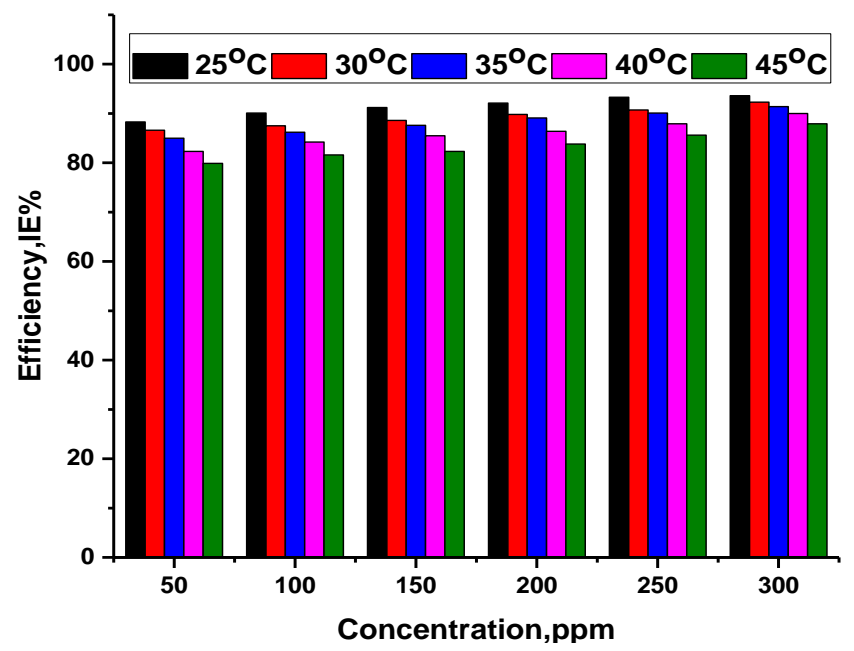

Figure 2. Effect of concentration on the IE of Clindamycin drug at different temperatures

Slika 2. Uticaj koncentracije na IE leka Klindamicina na različitim temperaturama

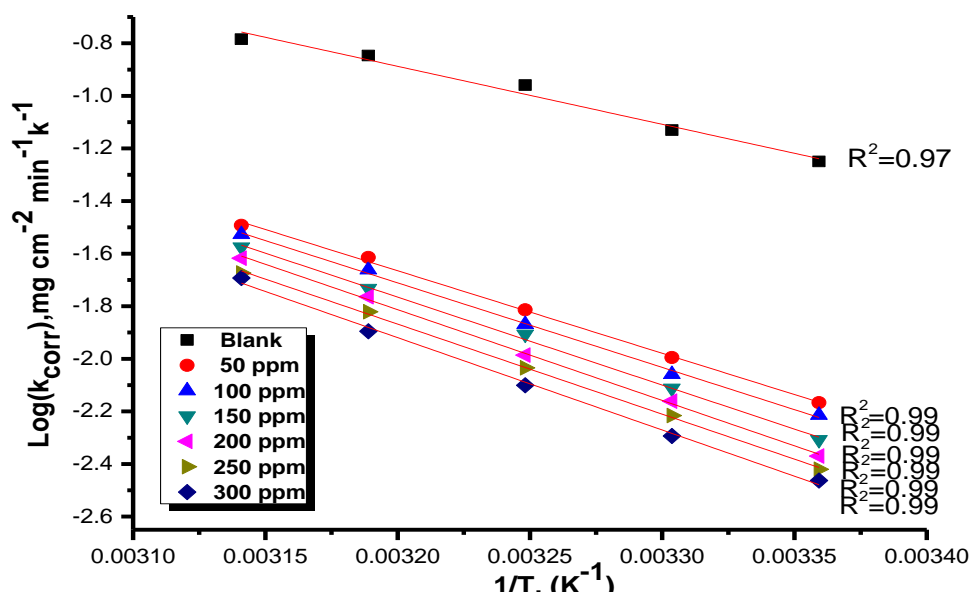

Figure 3. Arrhenius plots for the $k_{\text {corr }}$ of SS304 in $2 \mathrm{M} \mathrm{HCl}$ with and without Clindamycin drug at different temperatures

Slika 3. Arrhenius krive za $k_{\text {corr }}$ SS304 u 2M HCl sa i bez Klindamicina na različitim temperaturama

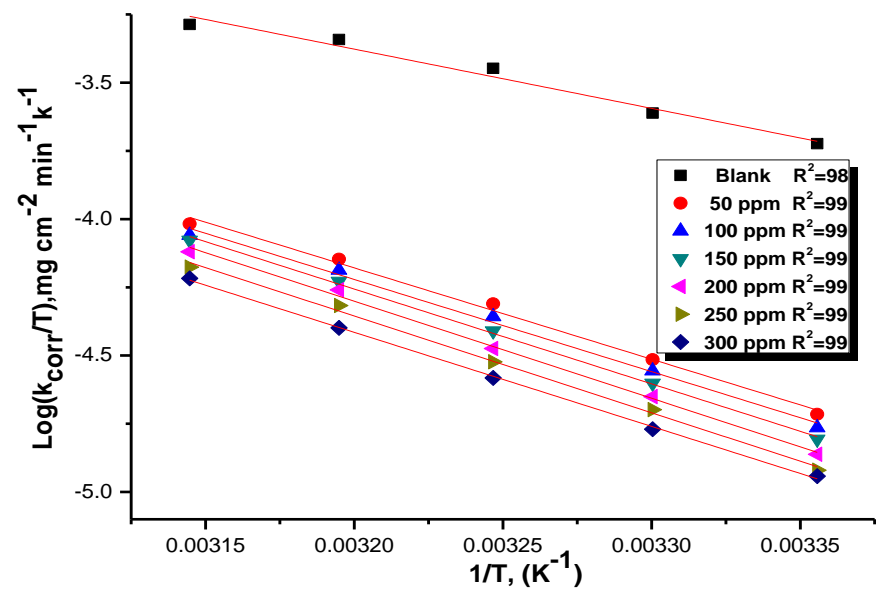

Figure 4. $\log \left(k_{\text {corr }} / T\right)$ versus $1 / T$ for SS 304 in $2 \mathrm{M} \mathrm{HCl}$ as blank and with Clindamycin drug at different temperatures

Slika 4. Log $\left(k_{\text {corr }} / T\right)$ prema 1/T za SS304 u $2 \mathrm{M} \mathrm{HCl} \mathrm{bez} \mathrm{i} \mathrm{sa} \mathrm{lekom} \mathrm{Klindamicin} \mathrm{na} \mathrm{različitim}$ temperaturama 
Fig. 4 shows a plot of $\log \mathrm{k}_{\text {corr }} / \mathrm{T}$ as a function of $1 / T$ for SS 304. Straight lines were obtained with a slope of $\Delta \mathrm{H}^{*} / \mathrm{R}$ and an intercept of $\ln \mathrm{R} / \mathrm{Nh}+\Delta \mathrm{S}^{*} / \mathrm{R}$ from which the values of $\Delta \mathrm{H}^{*}$ and $\Delta \mathrm{S}^{*}$ were calculated for the blank and Clindamycin drug. The values of the activation energy, enthalpy and entropy were recorded in (Table 5). The increase in the $E_{a}{ }^{*}$ is proportional to the drug concentration, indicating that the energy barrier for the corrosion process is also increased [31]. The increase in the $\left(\Delta \mathrm{H}^{*}\right)$ in presence of the drug means that the addition of the Clindamycin drug to the acid solution increases the height of the energy barrier of the corrosion reaction to an extent depends on the type and concentration of the present Clindamycin drug. The adsorption of the drug molecules on the metal surface leads to a lower number of hydrogen atoms adsorbed on it; this will cause a decrease in hydrogen evolution rate rather than the rate of metal dissolution, because of the blocking of the surface of the metal by the drug molecules.

Table 5. Activation parameters for SS304 corrosion in the absence and presence of various concentrations of Clindamycin drug in $2 \mathrm{M} \mathrm{HCl}$

Tabela 5. Aktivacioni parametri za koroziju SS304 u odsustvu i prisustvu različitih koncentracija leka Klindamicina u $2 \mathrm{M} \mathrm{HCl}$

\begin{tabular}{|c|c|c|c|}
\hline \multicolumn{3}{|c|}{ Activation parameters } & \multirow{2}{*}{ Conc., ppm } \\
\cline { 1 - 3 } $\begin{array}{c}-\Delta \mathrm{S}^{*}, \\
\mathrm{~J} \mathrm{~mol}^{-1} \mathrm{~K}^{-1}\end{array}$ & $\begin{array}{c}\Delta \mathrm{H}^{*}, \\
\mathrm{~kJ} \mathrm{~mol}^{-1}\end{array}$ & $\begin{array}{c}\mathrm{E}_{\mathrm{a}}{ }^{*}, \\
\mathrm{~kJ} \mathrm{~mol}^{-1}\end{array}$ & \\
\hline 119.1 & 45.5 & 48.2 & Blank \\
\hline 67.3 & 66.3 & 66.9 & 50 \\
\hline 64.5 & 68.7 & 68.2 & 100 \\
\hline 53.6 & 71.1 & 70.4 & 150 \\
\hline 49.9 & 74.4 & 73.7 & 200 \\
\hline 47.4 & 74.9 & 74.5 & 250 \\
\hline 46.5 & 76.0 & 75.2 & 300 \\
\hline
\end{tabular}

\subsection{Adsorption isotherms}

Assuming the studied drug affect the rate of the corrosion process at most through the variation of the $(\theta)$. Consequently, the IE is a function of the electrode surface covered by the inhibitor molecules, i.e. $\theta=\mathrm{IE} / 100$. Attempts were made to fit the relationship between $\theta$ and the bulk concentration of the inhibitor used at a certain given temperature in order to give an insight into the adsorption process. Several adsorption isotherms are commonly tried to characterize the inhibitor performance and the best fit was obtained using Langmuir isotherm, which assumes that the solid surface contains a fixed number of adsorption sites and each site holds one adsorbed species
[32] in good agreement with the following equation (7):

$$
C / \theta=1 / K_{a d s}+C
$$

where $\mathrm{K}_{\mathrm{ads}}$ is the equilibrium constant of the adsorption process. A plot of $(C / \theta)$ versus $(C)$ of Clindamycin drug at different temperatures is presented in Fig. 5 suggests that there are no attraction or repulsion forces between the adsorbed molecules, since a linear relationship is obtained with a slope equal to unity and intercept equal to $1 / K_{a d s}$, The adsorption equilibrium constant being related to the standard free energy of adsorption $\left(\Delta \mathrm{G}^{\circ}\right.$ ads $)$ by the relation (8):

$$
K_{a d s}=(1 / 55.5) \exp \left(\Delta G^{o}{ }_{a d s} / R T\right)
$$

where the constant 55.5 is the molar concentration of water in solution in $\mathrm{M}^{-1}$. By applying Eq. 6 , we obtain different values of $\Delta \mathrm{G}^{\circ}$ ads for the drug as a function of temperature in the domain $25-40{ }^{\circ} \mathrm{C}$ were obtained and are listed in (Table 6). The results of this Table showed the dependence of $\Delta \mathrm{G}^{\circ}$ ads on the absolute temperature (T). Fig.6 shows the relation between $\Delta \mathrm{G}_{\text {ads }}^{\circ}$ and $\mathrm{T}$. A linear plot was obtained with high regression constant (0.99) and with a slope equal to the entropy of adsorption $\left(\Delta S^{\circ}{ }_{\text {ads }}\right)$ and intercept equal to the enthalpy of adsorption $\left(\Delta \mathrm{H}_{\text {ads }}^{\circ}\right)$, according to equation (9):

$$
\Delta G^{\circ}{ }_{a d s}=\Delta H^{\circ} \text { ads }-T \Delta S^{\circ}{ }_{a d s}
$$

The various thermodynamic functions for the adsorption process $\left(\mathrm{K}_{\mathrm{ads}}, \Delta \mathrm{G}_{\mathrm{ads}}^{\circ}, \Delta \mathrm{H}_{\mathrm{ads}}^{\circ}\right.$, and $\Delta \mathrm{S}_{\mathrm{ads}}^{\circ}$ ) are given in (Table 6).

Table 6. Kinetic parameters for the corrosion of SS 304 in $2 \mathrm{M} \mathrm{HCl}$ at different temperatures

\begin{tabular}{|c|c|c|c|c|}
\hline $\begin{array}{l}\text { Temp } \\
\stackrel{\circ}{ } \text { C }\end{array}$ & $\begin{array}{l}\mathrm{K}_{\text {ads, }} \\
\mathrm{M}^{-1}\end{array}$ & $\begin{array}{l}-\Delta \mathrm{G}^{\mathrm{o}} \mathrm{ads}, \\
\mathrm{kJ} \mathrm{mol}^{-1}\end{array}$ & $\begin{array}{l}-\Delta \mathrm{H}^{\circ}{ }_{\text {ads }} \\
\mathrm{kJ} \mathrm{mol}^{-1}\end{array}$ & $\begin{array}{c}\Delta \mathrm{S}^{\circ}{ }_{\text {ads }} \\
\mathrm{J} \mathrm{mol}^{-1} \mathrm{~K}^{-1}\end{array}$ \\
\hline 25 & 201 & 23.3 & \multirow{4}{*}{26} & 78.1 \\
\hline 30 & 168 & 22.7 & & 76.5 \\
\hline 35 & 142 & 22.1 & & 75.2 \\
\hline 40 & 119 & 21.5 & & 73.6 \\
\hline 45 & 99 & 21.1 & & 72.2 \\
\hline
\end{tabular}

Tabela 6. Kinetički parametri za koroziju SS304 u 2M $\mathrm{HCl}$ na različitim temperaturama

It is generally obvious that $\Delta \mathrm{G}^{\circ}$ ads have increasingly negative value, as the \% IE increases, which indicates that the tested drug is adsorbed spontaneously on SS 304 surface forming a relatively stable adsorbed layer. It is is known that values of $\Delta \mathrm{G}^{\circ}$ ads lower than $20 \mathrm{~kJ} \mathrm{~mol}^{-1}$ indicative of physical adsorption [33]. The value of $\Delta \mathrm{G}^{\circ}$ ads is approximately equal $21 \mathrm{~kJ} \mathrm{~mol}^{-1}$ indicate that the 
adsorption mechanism of the Clindamycin drug on SS304 surface involves physical adsorption. The $\mathrm{K}_{\mathrm{ads}}$ follows the same trend in the sense that $\mathrm{a}$ larger value of $\mathrm{K}_{\text {ads }}$ means more efficient adsorption and hence better IE. The negative sign of $\Delta \mathrm{H}_{\text {ads }}^{\circ}$ reveals that adsorption of the drug on SS304 surface from $2 \mathrm{M} \mathrm{HCl}$ solution is an

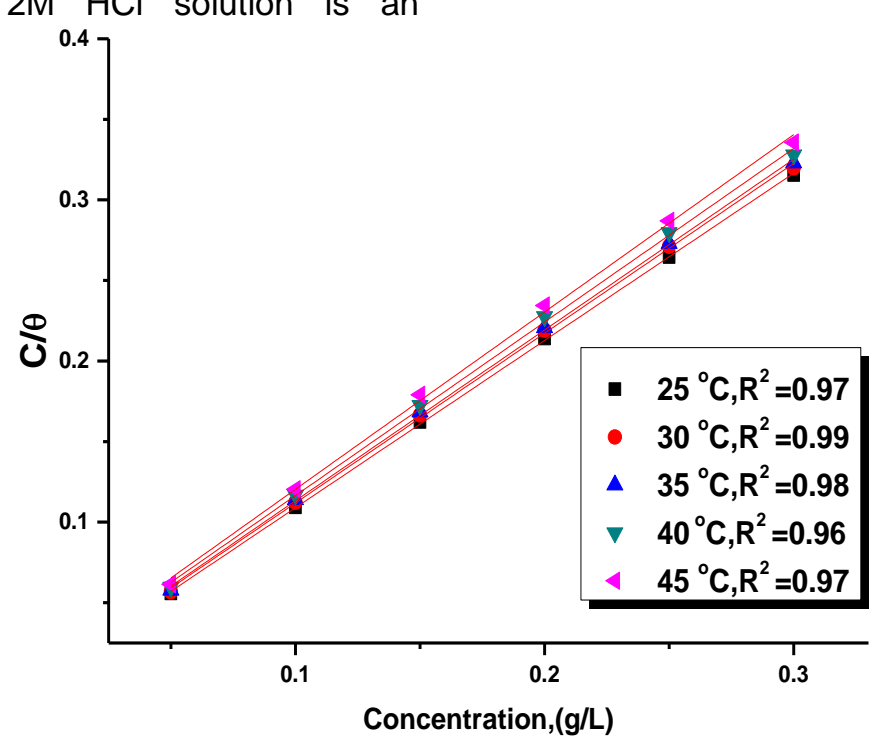

Figure 5. Langmuir adsorption isotherms for Clindamycin drug at different temperatures for SS304 in $2 \mathrm{M} \mathrm{HCI}$

Slika 5. Lengmirova adsorpciona izoterma za lek Klindamicin na različitim temperaturama za SS304 u $2 \mathrm{M} \mathrm{HCl}$

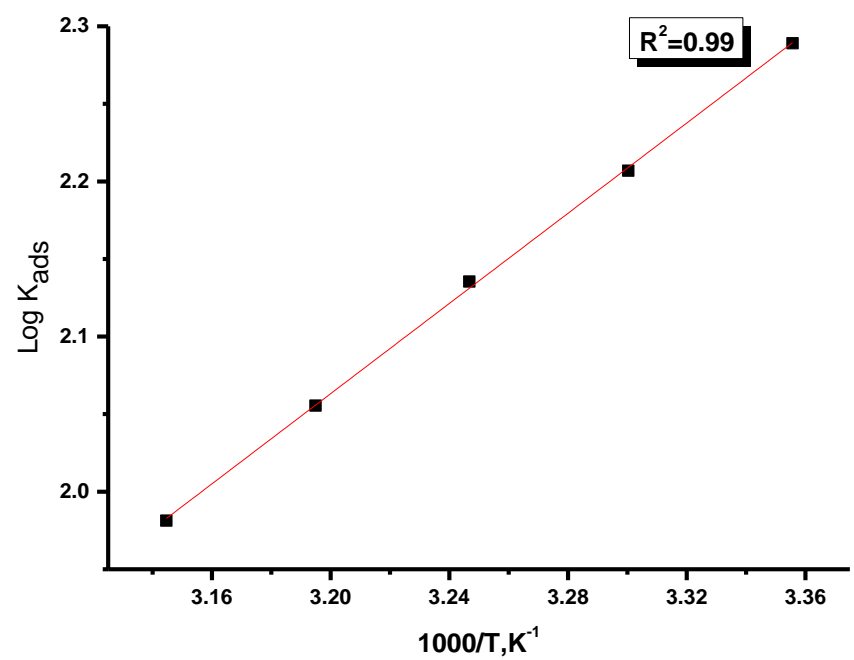

Figure 6. Log $K_{\text {ads }}$ vs $(1000 / T)$ for corrosion of SS304 in $2 \mathrm{M} \mathrm{HCl}$ in the presence of Clindamycin drug

Slika 6. Log $K_{a d s}$ vs (1000/T) za koroziju SS304 u 2M HCl u prisustvu leka Klindamicina

\subsection{Potentiodynamic polarization (PP) measurements}

The polarization curves for SS304 in $2 \mathrm{M} \mathrm{HCl}$ solution with and without Clindamycin drug are presented in Fig. 7. $i_{\text {corr }}$ densities were obtained from polarization curves by linear extrapolation of anodic and cathodic branches of Tafel slopes. The $(\% \mathrm{IE})$ and $(\Theta)$ were calculated from equation 5 exothermic process, which implies that \%IE for the drug decreases with the rise in temperature. Such behavior can be explained on the basis that temperature rise causes desorption of some adsorbed drug molecules on the SS 304 surface and hance lower protection was observed.
The electrochemical parameters such as corrosion potential $\left(E_{\text {corr }}\right)$, corrosion current density $\left(\mathrm{i}_{\text {corr }}\right)$, anodic Tafel constant $\left(\mathrm{b}_{\mathrm{a}}\right)$ and cathodic Tafel constant $\left(b_{c}\right)$ are presented in (Table 7$)$. From the Fig.7 and (Table 7) one can see when the concentration of Clindamycin drug was increased, the $\mathrm{i}_{\text {corr }}$ gradually decreased and the IE increased. The nearly steady values of $\left(E_{\text {corr }}\right)$ and the decreases of corresponding partial anodic and 
cathodic current densities, these data show that Clindamycin drug acts as mixed type inhibitor [3436]. Addition of Clindamycin drug has no significant effect on the values of anodic and cathodic Tafel slopes $\left(b_{a}, b_{c}\right)$. Therefore, the addition of this drug blocked the active sites of the electrode surface and decreasing the surface area available for corrosion reaction [37]. Therefore the presence of various concentrations of Clindamycin drug does not alter the corrosion mechanism. The experimental findings of PP curves were in good agreement with the data obtained in case of WL.

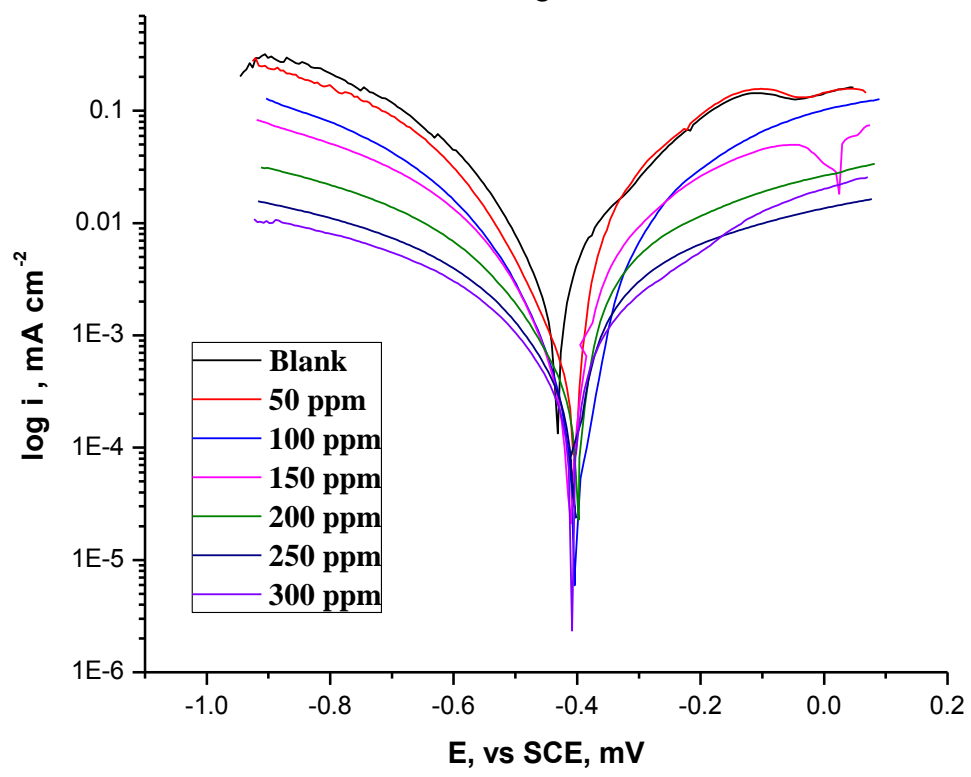

Figure 7. PP curves of SS304 corrosion with and without different concentrations of Clindamycin drug at $25^{\circ} \mathrm{C}$

Slika 7. PP krive korozije SS304 sa i bez različitih koncentracija leka Klindamicin na 25드

Table 7. Corrosion parameters in the presence and absence of Clindamycin drug obtained from PP measurements

Tabela 7. Parametri korozije u prisustvu i odsustvu leka Klindamicina dobijeni PP merenjem

\begin{tabular}{|c|c|c|c|c|c|c|c|}
\hline $\begin{array}{c}\text { Conc, } \\
\mathrm{ppm}\end{array}$ & $\begin{array}{c}\mathrm{i}_{\text {corr. }} \\
\mathrm{mA} \mathrm{cm}\end{array}$ & $\begin{array}{c}\mathrm{E}_{\text {corr. }} \\
\mathrm{mV} \text { vs SCE }\end{array}$ & $\begin{array}{c}\hat{\mathrm{a}}_{\mathrm{a}} \\
\left(\mathrm{mV} \mathrm{dec}^{-1}\right)\end{array}$ & $\begin{array}{c}\hat{\mathrm{a}}_{\mathrm{c}} \\
\left(\mathrm{mV} \mathrm{dec}^{-1}\right)\end{array}$ & $\begin{array}{c}\mathrm{k}_{\text {corr }} \\
\mathrm{mpy}\end{array}$ & $\theta$ & $\%$ IE \\
\hline 0.0 & 995 & 433 & 120.0 & 151 & 390 & $-\cdots$ & ---- \\
\hline 50 & 139 & 429 & 118.0 & 146 & 247 & 0.860 & 86.0 \\
\hline 100 & 131 & 428 & 110 & 148 & 235 & 0.868 & 86.8 \\
\hline 150 & 125 & 420 & 115 & 142 & 221 & 0.874 & 87.4 \\
\hline 200 & 101 & 410 & 105 & 140 & 218 & 0.898 & 89.8 \\
\hline 250 & 98 & 415 & 116 & 139 & 186 & 0.902 & 90.2 \\
\hline 300 & 86 & 408 & 109 & 145 & 110 & 0.913 & 91.3 \\
\hline
\end{tabular}

\subsection{Electrochemical impedance spectroscopy}

(EIS) measurements

Fig. 8 shows the Nyquist plot for SS304 in $2 \mathrm{M}$ $\mathrm{HCl}$ in the absence and presence of different concentrations of Clindamycin drug at $25^{\circ} \mathrm{C}$. This diagram has a semicircle appearance; it indicates that the corrosion of Clindamycin drug is mainly controlled by a charge transfer process. The Bode plot for the SS304 is shown in Fig. 9 where the high-frequency limit corresponds to electrolyte resistance $R_{\Omega}$, while the low-frequency limit represents the sum of $\left(R_{\Omega}+R_{p}\right)$ where $R_{p}$ is the first approximation determined by both the electrolytic conductance of the oxide film and polarization resistance of the dissolution and passivation process. Various impedance parameter such as charge transfer resistance $\left(R_{\mathrm{ct}}\right)$, double layer capacitance $\left(\mathrm{C}_{\mathrm{dl}}\right)$ and $(\% \mathrm{IE})$ was calculated 
and are given in (Table 8). The data obtained showed that the values of $\left(R_{c t}\right)$ increase and the values of capacitance double layer $\left(\mathrm{C}_{\mathrm{dl}}\right)$ decrease with increasing the concentration of the drug which accompanied with increasing (\% IE), due to the adsorption of this drug molecule on the electrode surface leading to a film formation on SS304 surface. The obtained Nyquist impedance diagram in most cases does not show perfect semicircle. This may be attributed to the frequency dispersion as a result of the heterogeneity of the electrode surface [38,39].

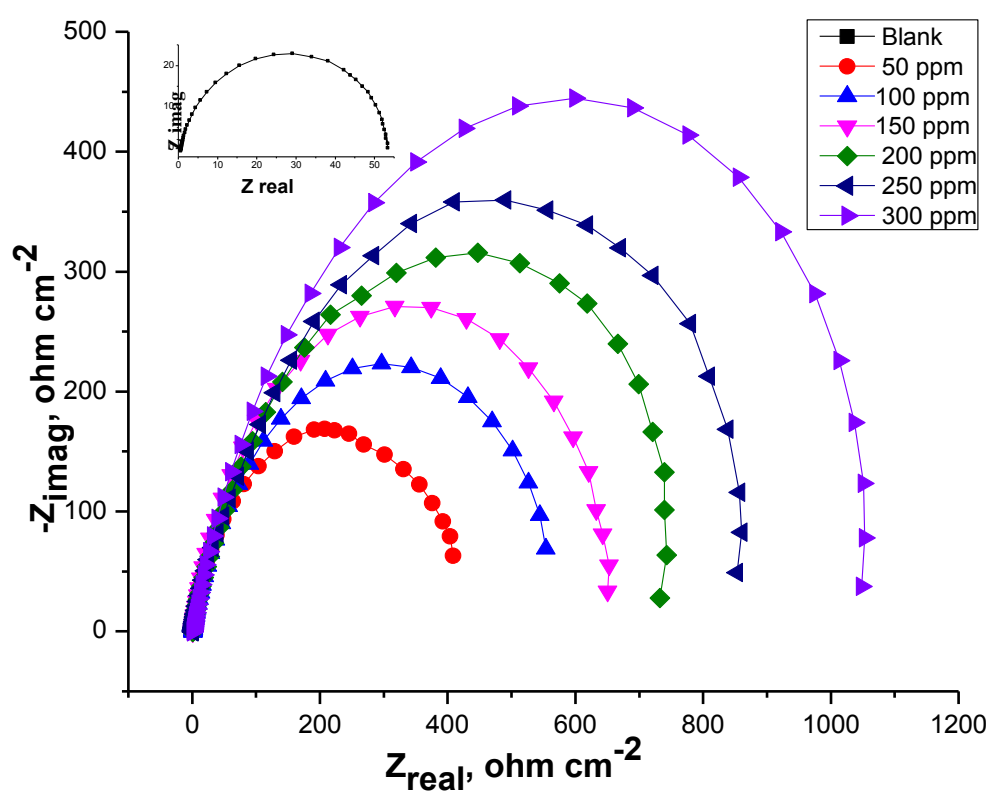

Figure 8. Nyquist plots for the corrosion of SS304 in $2 \mathrm{M} \mathrm{HCl}$ in the absence and presence of different concentrations of Clindamycin drug at $25^{\circ} \mathrm{C}$

Slika 8. NYQUIST spektri za koroziju SS304 u 2M HCl u odsustvu i prisustvu različitih koncentracija leka Klindamicin na $25^{\circ} \mathrm{C}$
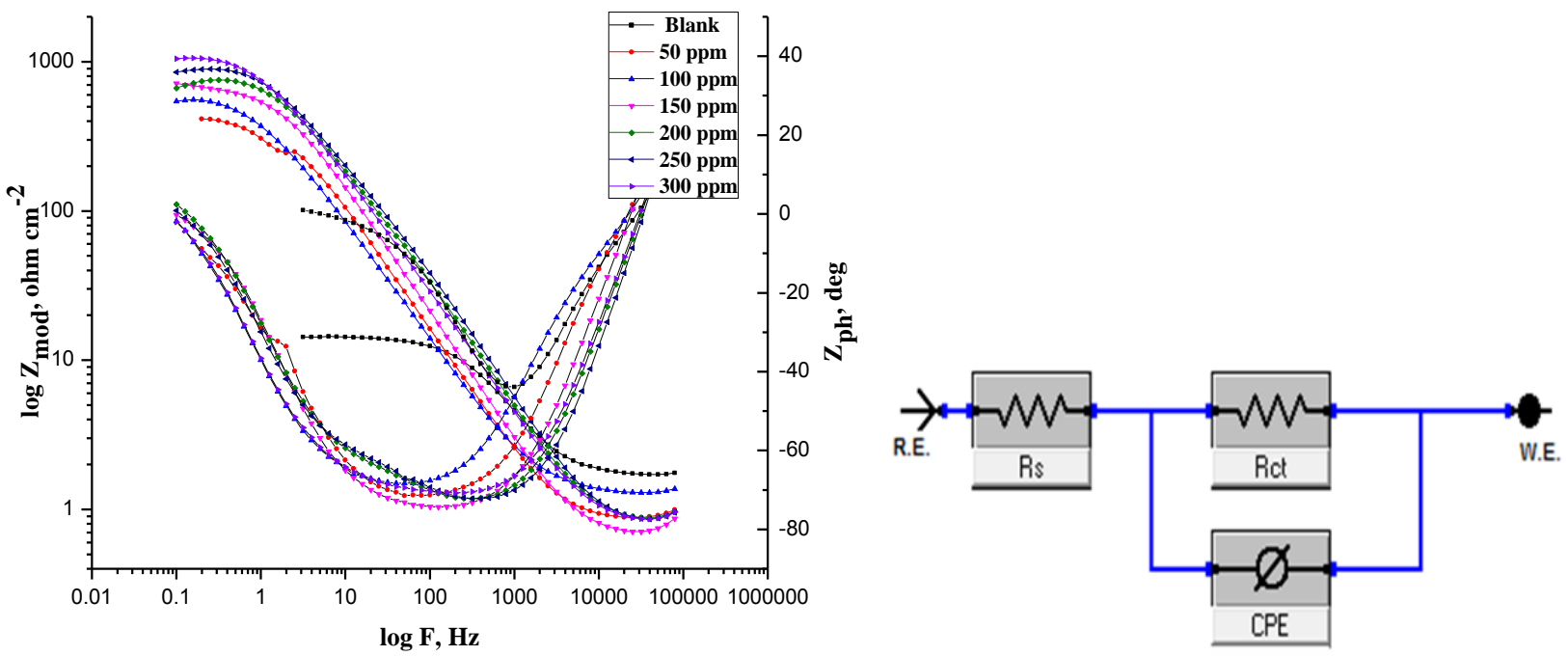

Figure 9. Bode plots for the corrosion of SS304 in $2 \mathrm{M} \mathrm{HCl}$ in the absence and presence of different concentrations of Clindamycin drug at $25^{\circ} \mathrm{C}$ and Equivalent circuit model used to fit the impedance spectra

Slika 9. Bode spektri za koroziju SS304 u $2 \mathrm{M} \mathrm{HCl}$ u odsustvu i prisustvu različitih koncentracija leka Klindamicin pri $25^{\circ} \mathrm{C}$ i model ekvivalentnog kola koji se koristi da se prilagodi spektru impedanse 
Table 8. EIS data of Clindamycin drug in $2 \mathrm{M} \mathrm{HCl}$ in the absence and presence of different concentrations of at $25^{\circ} \mathrm{C}$

Tabela 8. EIS podaci o leku klindamicina u $2 \mathrm{M} \mathrm{HCl} \mathrm{u}$ odsustvu i prisustvu različitih koncentracija na $25^{\circ} \mathrm{C}$

\begin{tabular}{|c|c|c|c|c|}
\hline Conc, ppm & $\mathrm{R}_{\mathrm{p}}, \Omega \mathrm{cm}^{2}$ & $\mathrm{C}_{\mathrm{dl}}, \mu \mathrm{F} \mathrm{cm}$ & $\theta$ & $\% \mathrm{IE}$ \\
\hline 0.0 & 48.9 & 216 & --- & --- \\
\hline 50 & 401.3 & 173 & 0.878 & 87.8 \\
\hline 100 & 583.8 & 122 & 0.916 & 91.6 \\
\hline 150 & 673.5 & 118 & 0.927 & 92.7 \\
\hline 200 & 761.1 & 92 & 0.936 & 93.6 \\
\hline 250 & 914.3 & 87 & 0.947 & 94.7 \\
\hline 300 & 1106 & 47 & 0.956 & 95.6 \\
\hline
\end{tabular}

\subsection{Electrochemical frequency modulation (EFM) technique}

EFM technique makes advantages of it an ideal candidate for online corrosion monitoring [40]. The great EFM strength is the causality factors which serve as an internal check on the validity of EFM measurement. The causality factors CF-2 and CF-3 are calculated from the frequency spectrum of the current responses. Figure (10) shows the EFM Intermodulation spectra (current vs. frequency) of SS 304 in $\mathrm{HCl}$ solution containing different concentrations of Clindamycin drug. The larger peaks were used to calculate the corrosion current density ( $\left.i_{\text {corr }}\right)$, the Tafel slopes $\left(b_{c}\right.$ and $\left.b_{a}\right)$ and the causality factors (CF-2 and CF-3). These electrochemical parameters were listed in (Table 9). The data presented in (Table 9) obviously show that the addition of Clindamycin drug at a given concentration to the acidic solution decreases the corrosion current density, indicating that this drug inhibits the corrosion of SS 304 in $2 \mathrm{M} \mathrm{HCl}$ through adsorption. The causality factors obtained under different experimental conditions are approximately equal to the theoretical values (2 and 3 ) indicating that the measured data are verified and of good quality. The \%IE $E_{\mathrm{EFM}}$ increases by increasing the drug concentration. Fig.10 shows the EFM Intermodulation spectra (current vs. frequency) of SS 304 in $\mathrm{HCl}$ solution containing different concentrations of Clindamycin drug.
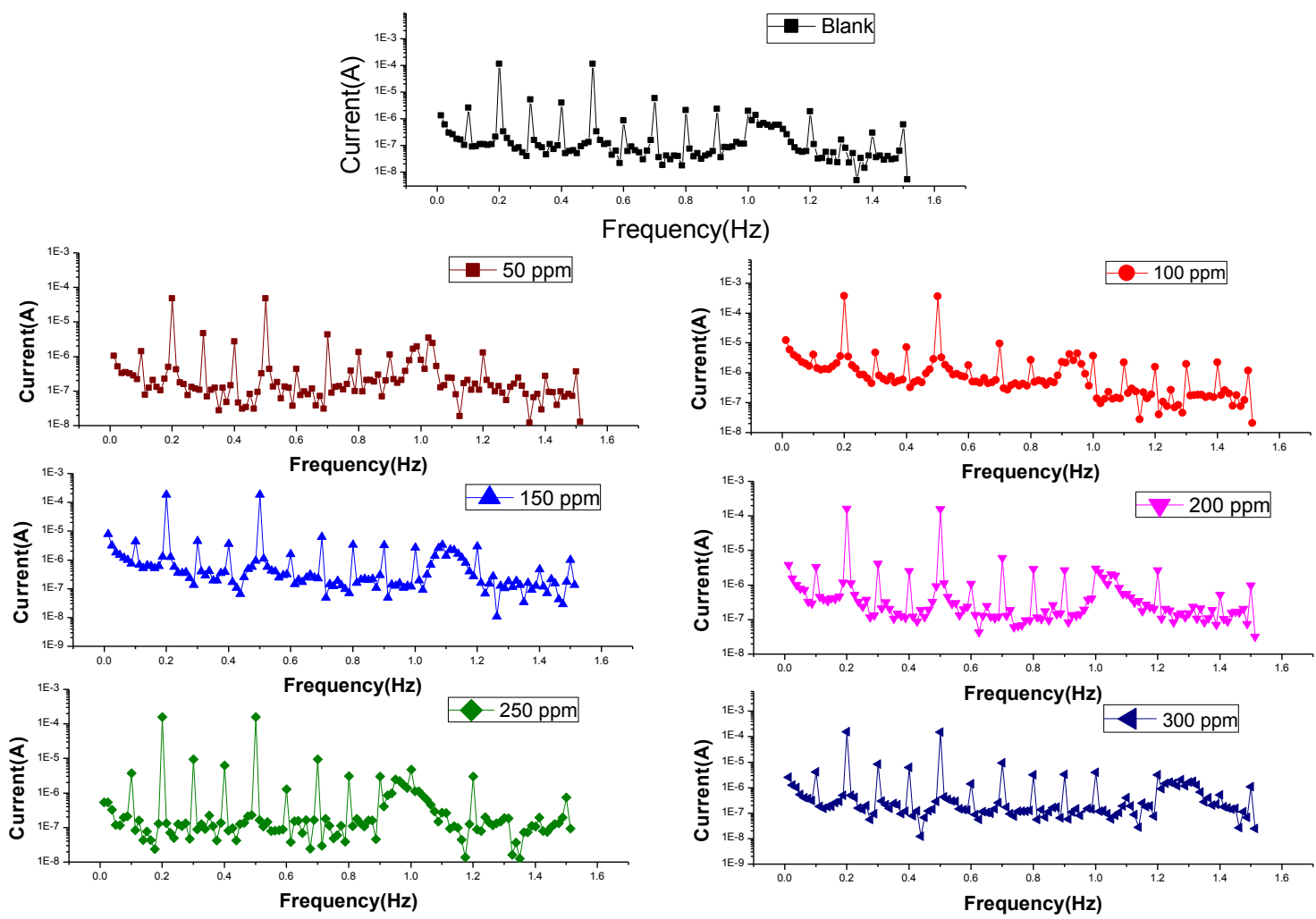

Figure 10. EFM spectra for SS304 in $2 \mathrm{M} \mathrm{HCl}$ in the absence and presence of different concentrations of Clindamycin

Slika 10. EFM spektri za SS304 u $2 \mathrm{M} \mathrm{HCl} \mathrm{u} \mathrm{odsustvu} \mathrm{i} \mathrm{prisustvu} \mathrm{različitih} \mathrm{koncentracija} \mathrm{Klindamicina}$ 
Table 9. Electrochemical kinetic parameters obtained by EFM technique for SS304 in the absence and presence of various concentrations of Clindamycin drug in $2 \mathrm{M} \mathrm{HCl}$ at $25^{\circ} \mathrm{C}$

Tabela 9. Elektrohemijski kinetički parametri dobijeni EFM tehnikom za SS304 u odsustvu i prisustvu različitih koncentracija Klindamicina u $2 \mathrm{M} \mathrm{HCl}$ na $25^{\circ} \mathrm{C}$

\begin{tabular}{|c|c|c|c|c|c|c|c|c|}
\hline $\begin{array}{c}\text { Conc, } \\
\mathrm{ppm}\end{array}$ & $\begin{array}{c}\mathrm{i}_{\text {corr. }} \\
\mu \mathrm{A} \mathrm{cm}\end{array}$ & $\begin{array}{c}\mathrm{a}_{\mathrm{a}} \\
\mathrm{mV} \mathrm{dec}^{-1}\end{array}$ & $\begin{array}{c}\hat{\mathrm{a}}_{\mathrm{c}} \\
\mathrm{mVdec}^{-1}\end{array}$ & CF-2 & CF-3 & $\begin{array}{c}\mathrm{k}_{\text {corr }} \\
\mathrm{mpy}\end{array}$ & $\theta$ & $\% \mathrm{IE}$ \\
\hline 0.0 & 777 & 105 & 126 & 1.80 & 2.90 & 355 & --- & --- \\
\hline 50 & 148 & 70 & 82 & 1.60 & 3.00 & 110 & 0.810 & 81.0 \\
\hline 100 & 138 & 76 & 93 & 1.90 & 2.70 & 102 & 0.822 & 82.2 \\
\hline 150 & 129 & 79 & 94 & 2.30 & 3.10 & 97 & 0.834 & 83.4 \\
\hline 200 & 110 & 69 & 91 & 1.80 & 3.40 & 87 & 0.858 & 85.8 \\
\hline 250 & 88 & 74 & 96 & 1.70 & 2.90 & 68 & 0.887 & 88.7 \\
\hline 300 & 56 & 81 & 96 & 2.00 & 2.80 & 25 & 0.928 & 92.8 \\
\hline
\end{tabular}

\subsection{Surface Examinations}

\subsubsection{AFM analysis}

AFM technique supplies photos with atomic or near-atomic-resolution surface topography which able to giving the surface roughness of coupons by the angstrom-scale. Atomic force microscopy (AFM) is a very higher resolution type of scanning probe microscopy on the order of fractions of a nanometer, more than 1000 times better than the optical diffraction limit [41]. Fig.11a shows the three dimensional (3D) AFM morphologies for polished
SS 304 surface as a standard sample, Fig. $11 \mathrm{~b}$ SS 304 surface immersed in $2 \mathrm{M} \mathrm{HCl}$ as a blank sample and Fig.11c SS 304 surface immersed in 2 $\mathrm{M} \mathrm{HCl}+300 \mathrm{ppm}$ of Clindamycin drug. AFM image analysis was carried out to obtain the roughness average (Sa), the root mean average (Sq) and the peak height (Sp) for the polished SS 304 (free sample), SS 304 surface immersed in $2 \mathrm{M} \mathrm{HCl}$ (blank sample) and SS 304 surface immersed in 2 $\mathrm{M} \mathrm{HCl}+300 \mathrm{ppm}$ of Clindamycin inhibitor. The obtained data from AFM analysis was listed in (Table 10)

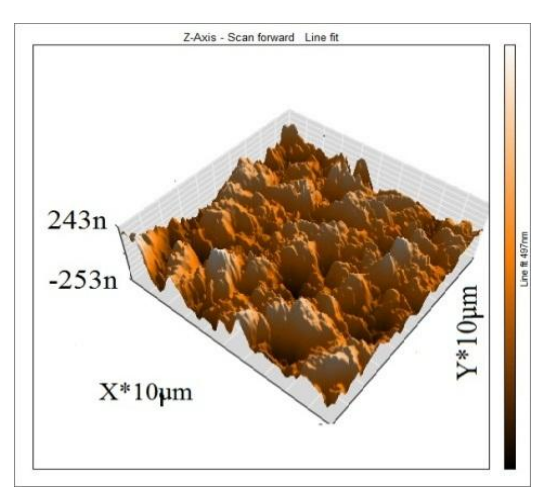

a)free

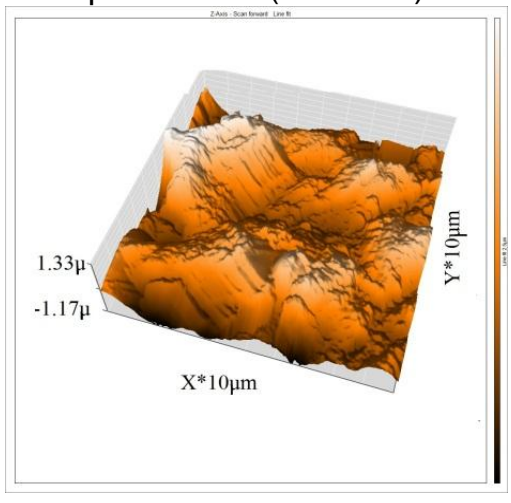

b) blank,

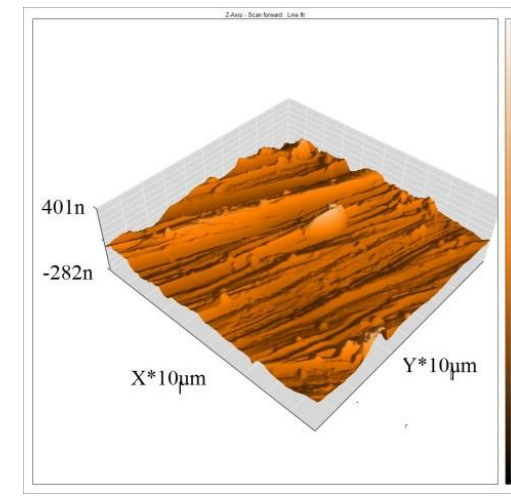

c) inhibitor

Figure 11. AFM analysis on SS304 in presence and absence of drug for 1 day's immersion

Slika 11. AFM analiza uzorka SS304 u prisustvu i odsustvu leka za 1 dan uranjanja

Table 10. AFM data for SS304 surface with and without drug (300 ppm)

Tabela 10. AFM podaci za površinu SS304 sa i bez leka (300 ppm)

\begin{tabular}{|l|c|c|c|}
\hline \multicolumn{1}{|c|}{ Sample } & Sa & Sq & Sp \\
\hline Free & 28.2 & 40.1 & 236 \\
\hline Blank & 382 & 501 & 1361 \\
\hline inhibitor & 58.5 & 73.1 & 273 \\
\hline
\end{tabular}

\subsubsection{FTIR analysis}

FTIR spectroscopy displays interesting features such as high signal to noise ratio, high sensitivity and selectivity, accuracy, mechanical simplicity, short analysis time and a small amount of sample required for the analysis. Fig.12 shows the FTIR spectra of the Clindamycin drug. The finger print spectra of the stock drug and the SS304 surface after immersion in $2 \mathrm{M} \mathrm{HCl}+300 \mathrm{ppm}$ of Clindamycin for 24 hours was obtained and 
compared to each other it was obviously clear that the same finger print of drug stock solutions present on 304 SS surface except the absence of some functional group and it suggested to be due to reaction with $\mathrm{HCl}$. From Fig.12 there is a small shift in the peaks at SS304surface from the original peak of the stock drug solution, these shifts indicate that there is an interaction between SS 304 and the inhibitor molecule.

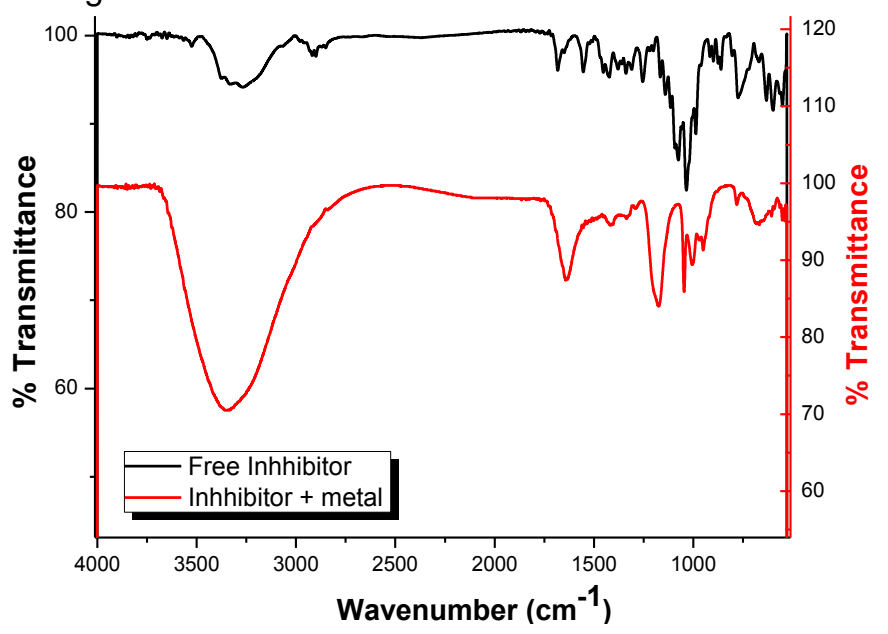

Figure 12. IR spectrum of pure Clindamycin at $25^{\circ} \mathrm{C}$

Slika 12. IR spektar čistog klindamicina na $25^{\circ} \mathrm{C}$

\subsection{Mechanism of corrosion inhibition}

The adsorption of drug molecules can be attributed to the existence of polar unit having atoms of nitrogen and oxygen and aromatic/heterocyclic rings. Therefore, the possible reaction centers are unshared electron pair of hetero-atoms and $\pi$ electrons of the aromatic ring [42]. The adsorption and IE of drug molecules in $2 \mathrm{M} \mathrm{HCl}$ solution can be explained as follows: In aqueous acidic solutions, drug molecules exist either as neutral molecules or as protonated molecules and may adsorb on the metal/acid solution interface by one and/or more of the following ways: (i) electrostatic interaction of protonated molecules with already adsorbed chloride ions, (ii) interaction between unshared electron pairs of hetero-atoms and vacant d-orbital of iron surface atoms. The possible explanation of the inhibition is due to the adsorption process which is considered as the key to the mechanism of inhibition action. It might be proposed that the drug molecules adsorb on the steel surface either as a neutral molecule or as protonated one.

Table 11. Comparison of results obtained with different eco-friendly (drugs) for mild steel in different acid environments

Tabela 11. Poređenje rezultata dobijenih sa različitim ekološki prihvatljivim (lekovima) za meki čelik u različitim kiselim sredinama

\begin{tabular}{|l|c|c|c|c|}
\hline \multicolumn{1}{|c|}{ Inhibitor (drug) } & Sample & Medium & IE \% & References \\
\hline Penicillin $\mathrm{G}\left(15 \times 10^{-4} \mathrm{M}\right)$ & Mild steel & $\mathrm{H}_{2} \mathrm{SO}_{4}$ & 90.0 & $(45)$ \\
\hline Penicillin V $\left(15 \times 10^{-4} \mathrm{M}\right)$ & Mild steel & $\mathrm{H}_{2} \mathrm{SO}_{4}$ & 63.3 & $(46)$ \\
\hline Cefalexin $\left(11 \times 10^{-4} \mathrm{M}\right)$ & Mild steel & $\mathrm{HCl}$ & 67.5 & $(47)$ \\
\hline Ceftriaxone $(400 \mathrm{ppm})$ & Mild steel & $\mathrm{HCl}$ & 87,6 & $(48)$ \\
\hline Cefotaxime $(300 \mathrm{ppm})$ & Mild steel & $\mathrm{HCl}$ & 90.0 & $(49)$ \\
\hline Cefixime $\left(8.8 \times 10^{-4} \mathrm{M}\right)$ & Mild steel & $\mathrm{HCl}$ & 62.0 & $(50)$ \\
\hline Ceftobiprole $\left(9.31 \times 10^{-4} \mathrm{M}\right)$ & Mild steel & $\mathrm{HCl}$ & 92.2 & $(51)$ \\
\hline Norfloxacin $(50 \mathrm{ppm})$ & Mild steel & $\mathrm{HCl}$ & 22.3 & $(52)$ \\
\hline Ciprofloxacin $(50 \mathrm{ppm})$ & Mild steel & $\mathrm{HCl}$ & 20.8 & $(52)$ \\
\hline Pefloxacin $(50 \mathrm{ppm})$ & Mild steel & $\mathrm{HCl}$ & 15.1 & $(52)$ \\
\hline Amifloxacin $(50 \mathrm{ppm})$ & Mild steel & $\mathrm{HCl}$ & 17.1 & $(52)$ \\
\hline Enrofloxacin $(50 \mathrm{ppm})$ & Mild steel & $\mathrm{HCl}$ & 18.3 & $(52)$ \\
\hline Clindamycin $(300 \mathrm{ppm})$ & Mild steel & $\mathrm{HCl}$ & 95.6 & Our results \\
\hline
\end{tabular}


This leads to a decrease of the surface area at which cathodic and anodic reactions take place. IE of the drug molecule depends on many factors [43], which include the number of adsorption active centers in the molecule and their charge density, molecular size, and mode of interaction with metal surface $[44,45]$. Shows a summary of the main results obtained with the use of different green inhibitors for mild steel in different acid environments. In all cases, including in this work, high-efficiency values, higher than $96 \%$ were obtained, which is very encouraging.

\section{CONCLUSIONS}

The Clindamycin drug acts as a good and efficient corrosion inhibitor for the corrosion of SS 304 in $2 \mathrm{M} \mathrm{HCl}$ solution. The IE decreases with rising of temperature but increases with increasing the dose of the drug. The inhibition of SS 304 corrosion by Clindamycin drug can be attributed to the adsorption ability of drug molecules onto the reactive sites of the metal surface. The adsorption of the drug on SS 304 obeys Langmuir adsorption isotherm. Polarization data indicate that the drug acts as a mixed-type inhibitor. AFM reveals the formation of a smooth uniform surface on SS 304 in the presence of the drug that indicates the formation of a good protective layer on the metal surface. The results obtained from different measurements gave consistent results.

\section{REFERENCES}

[1] M.Behpour, S.M.Ghoreishi, N.Soltani, M.SalavatiNiasari (2009) The inhibitive effect of some bis-N, S-bidentate Schiff bases on corrosion behavior of 304 stainless steel in hydrochloric acid solution, Corros. Sci. 51(5), 1073- 1082.

[2] M.Behpour, S.M.Ghoreishi, M.Khayat Kashani, N. Soltani (2009) Inhibition of 304 stainless steel corrosion in acidic solution by Ferula gumosa (galbanum) extract, Mater. Corros. 60, 895-898.

[3] F.Eghbali, M.H.Moayed, A.Davoodi, N.Ebrahimi (2011) Critical pitting temperature (CPT) assessment of 2205 duplex stainless steel in $0.1 \mathrm{M}$ $\mathrm{NaCl}$ at various molybdate concentrations Corros. Sci. 53, 513-522.

[4] M.Abdallah (2002) Rhodanine azosulpha drugs as corrosion inhibitors for corrosion of 304 stainless steel in hydrochloric acid solution, Corros. Sci. 44: 717-728.

[5] A.S.Fouda, A.S.Ellithy (2009) Inhibition effect of 4phenylthiazole derivatives on corrosion of $304 \mathrm{~L}$ stainless steel in $\mathrm{HCl}$ solution, Corros. Sci. 51, 868875 .

[6] H.Baseri, S.Tizro (2017) Treatment of nickel ions from contaminated water by magnetite-based nanocomposite adsorbents: Effects of thermo- dynamic and kinetic parameters and modeling with Langmuir and Freundlich isotherms, J. Process Safety and Environmental Protection, 109, 465-477.

[7] E.Ebenso, T.Arslan, F.Kandemirli, C.Necmettin, L.Ian (2009) Quantum chemical studies of some rhodanine azosulpha drugs as corrosion inhibitors for mild steel in acidic medium, International Journal of Quantum Chemistry, 110(5), 1003-1018.

[8] A.I.Adawy, M.A.Abbas, K.Zakaria (2016) A green organocatalyzed one-pot protocol for the efficient synthesis of newly substituted pyrimido[4,5- $d$ ] pyrimidinones using a Biginelli-like reaction, Res. Chem. Intermed. 42(4), 8185-8200.

[9] M.A.Deyab, S.T.Keera, S.M.El Sabagh (2011) Chlorhexidine digluconate as a corrosion inhibitor for carbon steel dissolution in emulsified diesel fuel, Corros. Sci. 53: 2592-2597.

[10] M.A.Deyab (2014) Adsorption and inhibition effect of Ascorbyl palmitate on corrosion of carbon steel in ethanol-blended gasoline containing water as a contaminant, Corros. Sci. 80, 359-365.

[11] A.S.Fouda, A.M. El-Azaly (2018) Expired concor drug as potential nontoxic corrosion inhibitor for 304 stainless steel in hydrochloric acid solution, Zastita materijala, 59(2), 226-237.

[12] A.S.Fouda, M.A.Elmorsi, T.A.Fayed, A.F.Hassan, M.Soltan (2014) Corrosion Inhibitors Based on Antibiotic Derivatives for Protection of Carbon steel Corrosion in Hydrochloric Acid Solutions, International Journal of Advanced Research, 2(4),788-807.

[13] N.O.Eddy, S.R.Stoyanov, E.Ebenso (2010) Fluoroquinolones as Corrosion Inhibitors for Mild Steel in Acidic Medium; Experimental and Theoretical Studies, Int. J. Electrochem. Sci., 5, 1127-1150.

[14] A.Samide, B.Tutunaru, C.Negrila (2011) Corrosion Inhibition of Carbon Steel in Hydrochloric Acid Solution Using a Sulfa Drug Chem. Bio chem. Eng., 25:299-308.

[15] K.N.Mohan, S.S.Shivakumar, A.M.Badie (2011) Inhibition of Mild Steel Corrosion in $0.25 \mathrm{M}$ Sulphuric Acid Solution by Imatinib Mesylate, Journal of the Korean Chemical Society, 55(3), 364372.

[16] J.A.Von Fraunhofer, S.H.Stidham (1991) Effects of fused-ring antibiotics on metallic corrosion, $J$. Biochem. Eng., 13, 424-428.

[17] R.Solmaz, G.Kardas, B.Yazici, M.Erbil (2008) Investigation of adsorption and inhibitive effect of 2mercapto thiazoline on corrosion of mild steel in hydrochloric acid media, Electrochimica Acta, 53(20), 5941-5952.

[18] A.S.Fouda, H.A.Mostafa, H.M.El-Abbasy (2010) Antibacterial drugs as inhibitors for the corrosion of stainless steel type 304 in $\mathrm{HCl}$ solution, J Appl Electrochem, 40, 163-173.

[19] M.Abdallah, I.Zaafarany, J.H.Al-Fahemi, Y. Abdallah, A.S.Fouda (2012) Antibacterial Cephalosporin as Inhibitors for the Corrosion of Iron in 
Hydrochloric Acid Solutions, Int. J. Electrochem. Sci., 7, 6622-6637.

[20] D.Q.Zhanga, Q.R.Cai, X.M.He, L.X.Gao, G.S.Kim (2009) Corrosion inhibition and adsorption behavior of methionine on copper in $\mathrm{HCl}$ and synergistic effect of zinc ions, Mater. Chem. Phys., 114, 612 617.

[21] E.E.Oguzie (2005) Corrosion inhibition of mild steel in hydrochloric acid solution by methylene blue dye, Mater. Letters, 59, 1076-1079.

[22] M.M. El-Fass, N.A.Badawy, A.A.El-Bayaa, N.S Moursy (1995) The Influence of Simple Electrolyte on the Behaviour of Some Acid Dyes in Aqueous Media, Bulletin of the Korean Chemical Society, 16(5), 458-461.

[23] M.S.Morad (2008) Inhibition of iron corrosion in acid solutions by Cefadroxil: Behaviour near and at the corrosion potential, Corros. Sci., 50, 436-448.

[24] F.Mansfeld (1981) Recording and analysis of AC impedance data for corrosion studies, Corrosion, 36, 301-307.

[25] R.S.Daum, N.Eng (2007) Skin and Soft-Tissue Infections Caused by Methicillin-Resistant Staphylococcus aureus, J. Med., 357(4), 380-390.

[26] C.Gabrielli (1980) "Identification of Electrochemical processes by Frequency Response Analysis, Solarton Instrumentation Group, Technical Report Number 004/ 83, England

[27] M.El Achouri, S.Kertit, H.M.Gouttaya, B.Nciri, Y.Bensouda, L.Perez, M.R.Infante, K.Elkacemi (2001) Corrosion inhibition of iron in $1 \mathrm{M} \mathrm{HCl}$ by some Gemini surfactants in the series of alkanediyl$\alpha, \omega$-bis-(dimethyl tetradecyl ammonium bromide), Prog. Org. Coat., 43, 267-273.

[28] J.R.Macdonald, W.B.Johanson (1987) in J.R. Macdonald (Ed.), Theory in Impedance Spectroscopy, John Wiley\& Sons, New York

[29] S.F.Mertens, C.Xhoffer, B.C.Decooman, E. Temmerman (1997) Short-term deterioration of polymer-coated $55 \% \mathrm{Al}-\mathrm{Zn}-$ part 1 : behavior of thin polymer films., Corrosion, 53, 381-388.

[30] G.Trabanelli, C.Montecelli, V.Grassi, A.Frignani (2005) Electrochemical study on inhibitors of rebar corrosion in carbonated concrete $\mathrm{J}$. Cem. Concr. Res., 35, 1804-1813.

[31] A.J.Trowsdate, B.Noble, S.J.Haris, I.S.R.Gibbins, G.E.Thomson, G.C.Wood, (1996), The influence of silicon carbide reinforcement on the pitting behavior of aluminium, Corros. Sci., 38, 177-191.

[32] F.M.Reis, H.G. de Melo, I.Costa (2006) EIS investigation on Al 5052 alloy surface preparation for self-assembling monolayer, J. Electrochem. Acta, 51, 1780-1788.

[33] M.Lagrenee, B.Mernari, M.Bouanis, M.Traisnel, F.Bentiss (2002) Study of the mechanism and inhibiting the efficiency of 3,5-bis (4methylthiophenyl)-4H-1, 2, 4-triazole on mild steel corrosion in acidic media, Corros. Sci., 44, 573-588.

[34] E.Mc Cafferty, N.Hackerman (1972) Double Layer Capacitance of Iron and Corrosion Inhibition with Polymethylene Diamines J. Electrochem. Soc., 119, 146-154.

[35] H. Ma, S.Chen, L.Niu, S.Zhao, S.Li, D.Li (2002) Inhibition of copper corrosion by several Schiff bases in aerated halide solutions, J. Appl. Electrochem., 32, 65-72.

[36] E.Kus, F.Mansfeld (2006) An evaluation of the electrochemical frequency modulation (EFM) technique, Corros. Sci., 48, 965-979.

[37] G.A.Caigman, S.K.Metcalf, E.M.Holt (2000) Thiophene substituted dihydropyridine, J.Chem. Cryst., 30, 415-422.

[38] S.S.Abdel-Rehim, K.F.Khaled, N.S.Abd-Elshafi (2006) Electrochemical frequency modulation as a new technique for monitoring corrosion inhibition of iron in acid media by new thiourea derivative, Electrochim. Acta, 51, 3269-3278.

[39] S.Zhang, Z.Tao, W.Li (2009) The effect of some triazole derivatives as inhibitors for the corrosion of mild steel in $2 \mathrm{M}$ hydrochloric acid, Appl Surf Sci., 255, 6757-6763.

[40] H.Amar, T.Braisaz, D.Villemin (2008) Thiomorpholin-4-ylmethyl-phosphonic acid and morpholine-4-methyl-phosphonic acid as corrosion inhibitors for carbon steel in natural seawater et al., Mater Chem. Phys.,110,1-6.

[41] R.Kalaivani, B.Narayanasamy, J.A.Selvi ( 2009) Corrosion Inhibition by Prussian Blue et al., Port Electrochim Acta.,27, 177-184.

[42] J.Sathiyabama, S.Rajendran, A.A.Selvi (2009) Eosin as Corrosion Inhibitor for Carbon Steel in Well Water, Open Corrosion J., 2, 77-82.

[43] A.K.Singh, M.A.Quraishi (2010) Inhibitive effect of diethyl carbamazine on the corrosion of mild steel in hydrochloric acid, Corros. Sci., 52, 15-29.

[44] G.Avci (2008)corrosion inhibition of indole-3-acetic acid on mild steel in $0.5 \mathrm{M} \mathrm{HCl}$, Colloid Surf., 37 , 730-736.

[45] A.S.Fouda, K.Shalabi, A.E-Hossiany (2016) Moxifloxacin Antibiotic as Green Corrosion Inhibitor for Carbon Steel in $2 \mathrm{M} \mathrm{HCl}$, J Bio Tribo Corros, 2,18-26. 


\title{
IZVOD
}

\section{INHIBICIJA KOROZIJE NERĐAJUĆEG ČELIKA 304 U RASTVORU HLOROVODONIČNE KISELINE KORIŠĆENJEM ANTIBIOTIKA KLINDAMICINA KAO EKOLOŠKOG INHIBITORA}

\begin{abstract}
Zaštita od korozije nerđajućeg čelika 304 (SS 304) u 2M rastvorima $\mathrm{HCl}$ pomoću klindamicin antibiotika ispitivana je gubitkom težine (VL), postupkom elektrokemijske modulacione frekvencije (EFM), elektrokemijskom impedansnom spektroskopijom (EIS) i potenciodinamičkom polarizacijom (PP). Elektrohemijski rezultati su pokazali da je ovo jedinjenje efikasan inhibitor za nerđajući čelik SS304 i da je efikasnost dostigla 93\% na 300 ppm. Efikasnost inhibicije (IE) se povećava sa koncentracijom leka $i$ opada sa porastom temperature. Podaci iz elektrokemijskih merenja ukazuju da je lek funkcionisao adsorpcijom molekula na granici metal / korodent, inhibirajući i katodnu i anodnu polu reakciju procesa korozije. Adsorpcija ovog leka na površini SS304 prati izotermijsku adsorpciju Langmira. Proračunate su i diskutovane termodinamičke funkcije procesa aktivacije $i$ adsorpcije. Morfologija površine SS304 uzoraka je procenjena korišćenjem mikroskopije (AFM) i infracrvene spektroskopije Fourier-ove transformacije (FTIR).
\end{abstract}

KIjučne reči: SS 304, inhibicija korozije, HCl, AFM, FTIR, klindamicin antibiotic.

\author{
Naučni rad \\ Rad primljen: 28. 06. 2018. \\ Rad korigovan: 12. 08. 2018. \\ Rad prihvaćen: 25. 08. 2018. \\ Rad je dostupan na sajtu: www.idk.org.rs/casopis
}

(c) 2019 Authors. Published by Engineering Society for Corrosion. This article is an open access article distributed under the terms and conditions of the Creative Commons Attribution 4.0 International license (https://creativecommons.org/licenses/by/4.0/) 